\title{
Non-steroid anti-inflammatory drugs, prostaglandins, and cancer
}

\author{
Viola Allaj ${ }^{1}$, Changxiong Guo ${ }^{1}$ and Daotai $\mathrm{Nie}^{1,2^{*}}$
}

\begin{abstract}
Fatty acids are involved in multiple pathways and play a pivotal role in health. Eicosanoids, derived from arachidonic acid, have received extensive attention in the field of cancer research. Following release from the phospholipid membrane, arachidonic acid can be metabolized into different classes of eicosanoids through cyclooxygenases, lipoxygenases, or p450 epoxygenase pathways. Non-steroid anti-inflammatory drugs (NSAIDs) are widely consumed as analgesics to relieve minor aches and pains, as antipyretics to reduce fever, and as anti-inflammatory medications. Most NSAIDs are nonselective inhibitors of cyclooxygenases, the rate limiting enzymes in the formation of prostaglandins. Long term use of some NSAIDs has been linked with reduced incidence and mortality in many cancers. In this review, we appraise the biological activities of prostanoids and their cognate receptors in the context of cancer biology. The existing literature supports that these lipid mediators are involved to a great extent in the occurrence and progression of cancer.
\end{abstract}

\section{Introduction}

Dietary fat is an important energy source. Fatty acids that are produced from catabolism of fats compose an important aspect of a healthy diet. They are subcategorized into saturated (lack double bonds) and unsaturated (contain double bonds) fatty acids. Fatty acids, including polyunsaturated fatty acids (PUFA), are usually stored in phospholipids or triglycerides. Essential fatty acids are necessary polyunsaturated fats that the human body is unable to synthesize and must obtain through the diet. Two families with opposing effects belong to this category of fatty acids: linoleic acid (omega-6) and alpha-linolenic acid (omega-3), which are the precursors of arachidonic acid (AA) and eicosapentanoic acid respectively.

In humans, cellular AAs are mainly released from membrane phospholipids by phospholipase $\mathrm{A}_{2}$ and phospholipase C. AAs can also be cleaved from diacylglycerol and is a minor product of linoleic acid (LA) metabolism. Most obligate carnivores, however, cannot synthesize AA from LA and must obtain AA from dietary sources. Arachidonic acid can be metabolized through cyclooxygenase

\footnotetext{
* Correspondence: dnie@siumed.edu

${ }^{1}$ Department of Medical Microbiology, Immunology, and Cell Biology, Southern Illinois University School of Medicine and Simmons Cancer Institute, Springfield, IL 62794, USA

${ }^{2}$ Department of Medical Microbiology and Immunology, Southern Illinois University School of Medicine, PO Box 19626, Springfield, IL 62794, USA
}

(COX), lipoxygenase (LOX), or epoxygenase mediated pathways to form a variety of biologically active lipids, termed as eicosanoids. LOX-derived metabolites include hydroperoxyeicosatetraenoic acids (HpETE), leukotrienes (LT), and lipoxins (LX) [1]. The COX pathway produces prostaglandin (PG) $G_{2}$ and prostaglandin $\mathrm{H}_{2}$, which is further converted into other prostaglandins. The major prostanoids synthesized from $\mathrm{COX}$ include prostaglandin $\mathrm{E}_{2}$, prostaglandin $\mathrm{D}_{2}$, prostacyclin $\mathrm{I}_{2}$, prostaglandin $\mathrm{F}_{2 \mathrm{a}}$ and thromboxane $\mathrm{A}_{2}\left(\mathrm{TXA}_{2}\right)$ (Figure 1). Prostanoids are extensively studied for their involvement in a long list of adverse health conditions, including cancer, inflammation, thrombosis, arthritis and atherosclerosis.

Non-steroid anti-inflammatory drugs (NSAIDs) are widely consumed as analgesics to relieve minor aches and pains, as antipyretics to reduce fever, and as antiinflammatory medications. Most NSAIDs are nonselective inhibitors of cyclooxygenases (COX), the rate limiting enzyme in the formation of prostaglandin $\mathrm{H}_{2}$. Therefore, NSAIDs can reduce the formation of various prostanoids. A number of epidemiological studies have linked the long term use of some NSAIDs, especially aspirin, with reduced cancer incidence and most significantly, with reduced cancer mortality [2-4]. This paper aims to give a brief overview of the effect of cyclooxygenases and the prostanoid signaling in the initiation, progression and treatment of 


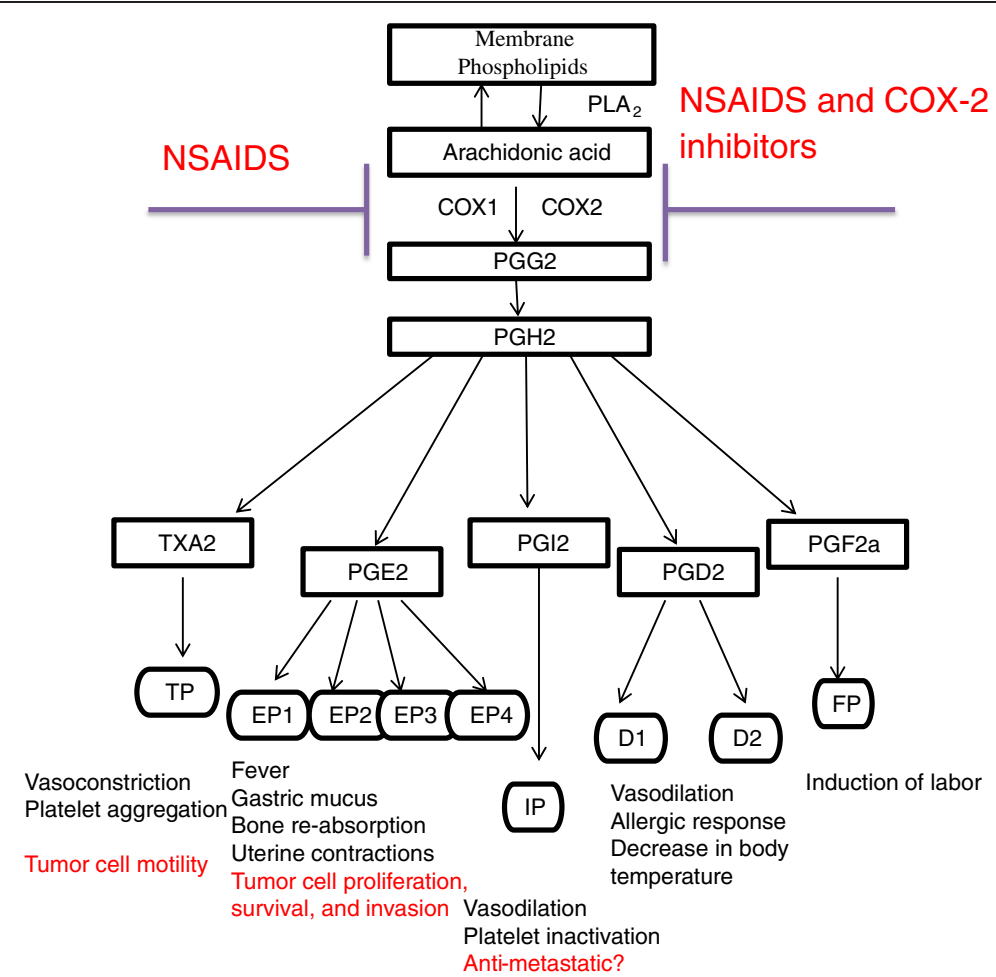

Figure 1 Biosynthesis and activities of prostaglandins and sites of NSAIDs actions. Cyclooxygenase metabolism of arachidonic acid can lead to the formation of prostaglandins that exert a variety of biological activities through their respective cognate receptors. The involvement of prostanoid receptors in cancer is also shown. Abbreviations: COX, cyclooxygenase; PG, prostaglandin; PLA 2 , phospholipase 2; TXA 2 , thromboxane $A_{2} ; T P$, thromboxane $A_{2}$ receptor; $E P$, prostaglandin $E_{2}$ receptor; $I P$, prostacyclin $\left(P G I_{2}\right)$ receptor; $D P$, prostaglandin $D_{2}$ receptor; $F P$, prostaglandin $F_{2}$ receptor; NSAIDs, non-steroid anti-inflammatory drugs.

cancer and provide an appraisal of NSAIDs utility in cancer prevention and treatment.

\section{Cyclooxygenases}

Currently, three known isoforms of COX exist: COX-1, COX-2, and COX-3. COX-1 and COX-2, also known as prostaglandin-endoperoxide synthase 1 and 2 respectively, catalyze the rate limiting step of prostaglandin synthesis. COX-1, encoded by the PTGS1 gene, is constitutively expressed in most mammalian tissues and appears to regulate normal physiological functions, including the maintenance of vascular homeostasis, mediation of allergic and immune responses, and stimulation of gastric mucosa production. COX-2, encoded by PTGS2 shares $81 \%$ homology with COX-1, is usually absent from healthy tissue and is transiently induced by pro-inflammatory stimuli, growth factors, cytokines, and tumor promoters to increase the rate of prostaglandin formation after tissue injury [1]. COX-3 is an alternately spliced variant of COX-1. Also encoded by the PTGS1 gene, COX-3 proteins retain an intron and a frame shift mutation, resulting in non-functional proteins in mice and humans [5].

When an appropriate PUFA binds to the COX active site, COX catalyzes the oxygenation of the substrate into
5-R,6-R',(1R,4S)-2,3-dioxabicyclo[2.2.1] heptane through a series of carbon radical intermediates. Both COX-1 and COX-2 primarily, but not exclusively, oxygenate AAs into prostaglandin $\mathrm{G}_{2} \mathrm{~S}\left(\mathrm{PGG}_{2}\right)$-at least three other minor products exist. $\mathrm{PGG}_{2} \mathrm{~S}$ are then reduced to prostaglandin $\mathrm{H}_{2} \mathrm{~S}$ $\left(\mathrm{PGH}_{2}\right)$ by peroxidases. $\mathrm{PGH}_{2}$ is subsequently converted into biologically functional molecules-including prostaglandin $\mathrm{E}_{2}\left(\mathrm{PGE}_{2}\right)$, which induces fever and stimulates gastric mucus production, bone re-absorption and uterine contractions; prostaglandin $\mathrm{D}_{2}\left(\mathrm{PGD}_{2}\right)$, which mediates vasodilatation, allergic response, and decreases in body temperature; prostacyclin $\left(\mathrm{PGI}_{2}\right)$, which potently induces vasodilatation and inhibits platelet activation; and thromboxane ( $\left.\mathrm{TXA}_{2}\right)$, which functions in contrast to $\mathrm{PGI}_{2}$ and potently induces vasoconstriction and platelet aggregation (Figure 1).

COX-1 and COX-2 also catalyze the oxygenation of other PUFAs, including dihomo- $\gamma$-linolenic acid (DGLA) to form the series-1 prostaglandin and thromboxane precursor $\mathrm{PGH}_{1}$ and series-1 thromboxane $\mathrm{TXA}_{1}$, eicosapentaenoic acid (EPA) to form series-3 prostaglandin precursor $\mathrm{PGH}_{3}$, and possibly linolenic acids to form 9- and 13-hydroxyoctadecadienoic acids (HODE) [6,7].

The COX enzymes are the primary targets of NSAIDs, including common over the counter medications such as 
aspirin, ibuprofen, and naproxen. By inhibiting the production of PGs, these drugs suppress the pathways that mediate inflammation, pain and fever. Long term use of some of these drugs appears to also offer limited protection against acute cardiac events, Alzheimer's disease, and neoplastic diseases, especially colorectal neoplasms. But the medications can potentially interfere with the production of gastrointestinal mucosa, significantly increasing the risk of gastrointestinal related side effects, including dyspepsia, abdominal pain and occasional perforations. More recently developed COX-2 specific inhibitors, such as rofecoxib (Vioxx), are not associated with GI related side effects, but appear to, along with ibuprofen, significantly increase the chances of acute myocardial infarction in already at risk patients-enough of a risk to prompt Merck to voluntarily withdraw Vioxx from market [1].

\section{Prostanoid signaling}

Prostanoids usually act within the tissue, where they are synthesized, via a carrier-mediated process [8] to activate the membrane receptors [9-11], or in some cases may interact with nuclear receptors [12]. The membrane receptors for prostanoids are termed P receptors, with a preceding letter indicating the natural prostanoid to which each receptor is most sensitive, i.e. DP, EP, FP, IP and TP for $\mathrm{PGD}_{2}, \mathrm{PGE}_{2}, \mathrm{PGF}_{2}, \mathrm{PGI}$, and $\mathrm{TXA}_{2}$, respectively $[13,14]$ (Figure 1 ). The membrane receptors for prostanoids are mainly heterotrimeric $G$ protein coupled receptors (GPCR). Below is a brief overview of GPCRs for prostanoid signaling.

EP: PGE $_{2}$ regulates diverse biological processes, including cell growth, inflammation, reproduction, sodium homeostasis and blood pressure [15]. Its biological effects are complex and often opposing; vasodilation in arterial and venous systems but constriction of smooth muscle in the trachea, gastric fundus and ileum [16]. Four EP receptor subtypes (EP1-4) have been cloned and characterized [17-21]. The mRNAs for all EPs are widely expressed. Although these four receptors uniformly bind $\mathrm{PGE}_{2}$ with high affinity, when examined on the basis of amino acid homology, they are not as closely related to each other as to other prostanoid receptors that use similar signaling mechanisms [14]. EP2 and EP4 are more closely related to IP and DP receptors, whereas EP1 and EP3 are more closely related to TP and FP receptors.

The EP1 was originally described as a smooth-muscle constrictor. It plays important roles in neuronal functions. The cloned human EP1 receptor cDNA encodes a 402-amino-acid polypeptide that signals via increased inositol-3-phosphate (IP3) generation and increased intracellular $\mathrm{Ca}^{2+}$ moblization $[17,22]$.

The human EP2 receptor cDNA encodes a 358amino-acid polypeptide that signals through increased cAMP [21,23]. EP2 receptor plays an important role in female reproduction, vascular hypertension and tumorigenesis [24]. The EP2 may also be an important target for treating asthma by promoting bronchodilation [25]. The EP2 is distinguished from the EP4 by its relative insensitivity to the EP4 agonist PGE1-OH [23]. EP2 mRNA is most abundant in the uterus, lung, and spleen, with only low levels of expression in the kidney $[23,26]$. It is expressed at much lower levels than EP4 mRNA in most tissues [27].

The EP3 receptors generally act as constrictors of smooth muscle [13]. It is associated with fever, gastric mucosal protection, pain hypersensitivity, kidney function and anti-allergic response. EP3 has at least nine alternatively spliced variants defined by unique C-terminal cytoplasmic tails [28]. These splice variants encode proteins with predicted molecular masses of between 40 and $45 \mathrm{kDa}$ [23]. The EP3 splice variants bind $\mathrm{PGE}_{2}$, agonists MB28767 and sulprostone with similar affinities as EP3 [14]. All of the splice variants uniformly and potently inhibit CAMP generation via a pertussis toxin-sensitive Gicoupled mechanism; however, $\mathrm{Ca}^{2+}$-dependent signaling mechanisms appear to be differentially activated by different C-terminal tails [29-31]. The physiological significance of these different $\mathrm{C}$-terminal splice variants may play a role in constitutive regulation of cellular events [32]. The receptor EP4 signals through increased cAMP [21] and is a systemic vasodepressor [33].

EP4 directs platelet inhibition at low $\mathrm{PGE}_{2}$ concentrations, but leads to EP3-mediated platelet aggregation at high concentration of $\mathrm{PGE}_{2}$ [34]. It also has roles in ductus arteriosus closure and inflammation associated bone resorption [35]. The human EP4 cDNA encodes a 488-amino-acid polypeptide with a predicted molecular mass of $53 \mathrm{kDa}$ [21]. EP4 may be pharmacologically distinguished from the EP1 and EP3 by their insensitivity to sulprostone and from EP2 by its insensitivity to butaprost $[26,36]$.

DP: $\mathrm{PGD}_{2}$ is the major COX product released by mast cells during allergic responses. It has been associated with the development of pulmonary inflammatory diseases such as asthma [37]. $\mathrm{PGD}_{2}$ also plays a role in regulating sleep-wake cycles [38] and pain perception [39]. Two receptors for $\mathrm{PGD}_{2}, \mathrm{DP} 1$ [40] and DP2 [41], have been cloned from human cells. DP1 is coupled positively to adenylyl cyclase though Gs [14] and this results in strong inhibitory effects on platelet aggregation, bronchodilation and vasodilation in humans [42,43]. DP2 (also known as CRTH2) is preferentially expressed in T-helper type 2 cells, eosinophils, and basophils. Activation of $\mathrm{DP}_{2}$ leads to mobilization of intracellular $\mathrm{Ca}^{2+}$. DP2 also directs $\mathrm{PGD}_{2}$-induced chemotaxis and migration of $\mathrm{TH} 2$ cells [44]. Both DP1 and DP2 integrate coordinately the effects of $\mathrm{PGD}_{2}$ on eosinophils, modulating chemokinesis, degranulation, and apoptosis [45]. 
FP: Prostaglandin $\mathrm{F}_{2 \alpha}\left(\mathrm{PGF}_{2 \alpha}\right)$ is synthesized from $\mathrm{PGH}_{2}$ via a PGF synthase or from $\mathrm{PGE}_{2}$ via a 9-keto reductase. $\mathrm{PGF}_{2 \alpha}$ is the trigger that initiates luteolysis or regression of the corpus luteum in the absence of pregnancy [46]. It is also a contractor of smooth muscle across a variety of tissues [47]. $\mathrm{PGF}_{2 \alpha}$ induces cardiac myocyte hypertrophy and induction of myofibrillar gene [48]. Thus far, one membrane receptor for $\mathrm{PGF}_{2 \alpha}(\mathrm{FP})$ in human cells has been cloned [49]. Stimulation of FP activates Rho kinase, leading to the formation of actin stress fibers, phosphorylation of p125 focal adhesion kinase, and cell rounding [50]. FP is highly expressed in skin, where it may play an important role in carcinogenesis [51]. FP also appears to have an important role in the eye, where it increases uveoscleral outflow and reduces ocular pressure [52].

IP: Prostacyclin $\left(\mathrm{PGI}_{2}\right)$ was first discovered in 1976 as an unstable eicosanoid in blood vessels [53]. It is very labile and undergoes spontaneous transformation to 6keto-PGF ${ }_{1 \alpha}$ within minutes in vivo [54]. Prostacyclin is a potent endogenous anticoagulator for platelets and a strong vasodilator [53]. It is the most abundant product of arachidonic acid in vascular tissues [55]. Like many other lipid mediators of the eicosanoid family derived from arachidonic acid, $\mathrm{PGI}_{2}$ is produced by the COX system. $\mathrm{PGI}_{2}$ synthase (PGIS) converts $\mathrm{PGH}_{2}$ to $\mathrm{PGI}_{2}$ [56]. On-site production of $\mathrm{PGI}_{2}$ is executed by either COX-1 or COX-2 coupled to PGIS [57]. However, $\mathrm{PGI}_{2}$ is a primary product of COX-2 in certain systems [58-60]. Prostacyclin signaling pathway involves both cell surface and nuclear receptors [61]. However, the classical signaling pathway of $\mathrm{PGI}_{2}$ is to use a $\mathrm{G}$ protein coupled receptor termed IP [62]. IP mRNA is abundantly expressed in kidney, liver, heart and lung [63]. Activation of IP by $\mathrm{PGI}_{2}$ leads to an increase in cAMP and activates protein kinase A cascade, or calcium mobilization via phospholipase C activation [64].

TP: Thrombosane $\mathrm{A}_{2}\left(\mathrm{TxA}_{2}\right)$ is produced from $\mathrm{PGH}_{2}$ by TX synthase. It is a modulator of platelet shape change and aggregation. $\mathrm{TxA}_{2}$ is a potent vasoconstrictor, mitogen and platelet activator [65-67]. TxA may also mediate cellular hypertrophy [68]. The human $\mathrm{TxA}_{2}$ receptor (TP) was the first eicosanoid receptor cloned in 1991 [69]. Two alternatively spliced variants of human TP have been described [70]. These variants differ in the C-terminal tail of the receptor distal to Arg328. The original placenta-derived clone of 343 amino acid residues receptor has been designated as TP $\alpha$, and a 407 residue splice variant cloned from endothelium is designated as TP $\beta$. TP mRNAs are expressed widely in the lung, liver, kidney, heart, uterus, and vascular cells with $\mathrm{TP} \alpha$ as the dominant isoform [71]. Both TP $\alpha$ and TP $\beta$ couple via $G_{q}, G_{11}$, and $G_{12 / 13}$ to activate PLCdependent inositol phosphate generation and elevate intracellular calcium [63]. Activation of TP by $\mathrm{TxA}_{2}$, or by more stable synthetic agonists, evokes the activation of phospholipase $\mathrm{C}$ and a subsequent rise in the intracellular calcium ion concentration, leading to vasoconstriction and platelet aggregation [72,73]. It is interesting to note that TP $\alpha$ and TP $\beta$ appear to dimerize, and their coexpression augments iPF $2 \alpha$-III (an isoprostane) signaling when compared to either receptor alone [74].

\section{Cyclooxygenases and cancer}

Speculation of COX enzymes' involvement in carcinogenesis and progression existed since 1976. That year, a small study showed that the osteolytic activities of 8 out of 9 osteolytically active tumors excised from patients with breast cancer were significantly inhibited by aspirin, a nonselective COX inhibitor [75]. Since then, aberrant over-expression of COX has been consistently associated with malignant transformation of healthy tissue, proliferation and increased invasiveness of malignant tissue, and unfavorable clinical outcomes. Up-regulations of COX enzymes have been reported in many human cancers and accumulation of $\mathrm{PGE}_{2}, \mathrm{PGF}_{2 \alpha}$ (a PGE $\mathrm{PG}_{2}$ derivative), and $\mathrm{PGI}_{2}$ are features of many epithelial cancers. COX-1 is up-regulated in cervical, ovarian and gallbladder cancers [1]. COX-2, which is normally undetectable in healthy tissue, is markedly over-expressed in colorectal, lung [76], prostate [77], cervical [78], ovarian [79], breast, gastric, pancreatic [80] and certain head and neck squamous cell [81] cancers. In the following paragraphs, we will examine the involvements of COXs in tumor initiation and progression in more depth.

\section{Cyclooxygenase involvement in tumor initiation}

Studies in the laboratory are establishing COX enzymes' roles in cancer initiation. Aberrant COX expression alone is not known to initiate tumors, but significant upregulation of these enzymes is frequently associated with premalignant alterations in epithelial tissues. In addition to causing chronic inflammation, immunological studies have shown that COX products, especially Prostaglandin $E_{2}$, interfere with the antitumor activities of the immune system. $\mathrm{PGE}_{2}$ inhibits $\mathrm{T}$ lymphocytes from producing antitumor $\mathrm{T}_{\mathrm{H}} 1$ cytokines and inhibit the antitumor functions of natural killer cells and macrophages [1]. Also, in tissues with low cytochrome P450 expressions, COX enzymes oxidize a significant amount of xenobiotics into mutagens and generate mutagens as by-products during prostaglandin synthesis [1]. Those endogenously produced mutagens can cause DNA damages as tumor initiators.

In vivo experiments have shown that $\mathrm{APC}^{\mathrm{Min}}$ mice lacking COX-2 develop $80 \%$ fewer intestinal neoplasias than mice that express wild type COX-2 [82], and these COX-2 deficient mice also develop $75 \%$ fewer papillomas than wild-type mice in a multistep tumor initiation/ 
promotion model [83]. Other studies have confirmed this correlation between COX-2 over-expression and premalignant and malignant lesions in epithelial tissues. Both pharmacological inhibition of COX-2 using celecoxib, a selective COX-2 inhibitor, and genetic knockout of COX-2 protected mice from UV-induced nonmelanoma skin cancers [84]. Mice that over-express COX-2 in basal epidermal cells, through keratin 5 promoters, are significantly more susceptible to genotoxic carcinogens than wild-type mice, and develop epidermal hyperplasia and dysplasia after single epicutaneous applications of $0.5 \mu \mathrm{M}$ DMBA in $0.1 \mathrm{ml}$ acetone [85].

Although there is strong evidence suggesting COX-2's involvement in tumor initiation, COX-1's functional role in carcinogenesis remains unclear - these same mice models have produced inconsistent data. While COX-1 deficient $\mathrm{APC}^{\mathrm{Min}}$ mice also presented with an $80 \%$ lower incidence of intestinal neoplasia [82], COX-1 deficiency offered no protection against skin cancers in the UVinduced carcinoma model [84]. The studies suggest a potential role for aberrant expression and activities of COX2, but less likely COX-1, in initiating tumor formation.

\section{Cyclooxygenase involvement in tumor growth and progression}

Further studies have identified the COX enzymes as important components for tumor growth, survival and progression. Clinical surveys have found an average of a 3.3 fold difference between the expression of COX-2 enzymes in malignant prostate cancer tissues and inflammatory benign prostate hyperplasia tissues [77]. The same study also found marked increases of Bcl-2, an apoptosis suppressor, and vascular endothelial growth factor (VEGF), an angiogenesis modulator linked to accelerated tumor progression and increased invasiveness, in malignant prostate tissues [77]. In vitro studies have confirmed the correlation between COX-2 and many of these observations. Treatment with $\mathrm{PGE}_{2}$ receptor (EP) antagonists and siRNA silencing of COX-2 in Hela cervical cancer cell coincides with sharp decreases in VEGF-C protein and mRNA expression respectively [86]. Stromal fibroblasts isolated from COX-2 deficient, but not COX-1 deficient, mice also produces far less (>90\%) VEGF than fibroblasts from wild-type mice [87]. Therefore, COX-2 appears to not only mediate tumor growth, but also it can elicit other changes from host tissues, such as neovascularization, to support tumor growth and progression.

Animal model experiments have echoed these findings. Although not statistically significant when compared to control groups, $25 \mathrm{mg} / \mathrm{kg}$ of body weight dose of celecoxib administered daily via gavage feeding tubes inhibited the growth of subcutaneously implanted SKOV-3 human ovarian carcinoma cells by $15 \%$ over
28 days in nude mice. Co-administration of celecoxib and $3 \mathrm{mg} / \mathrm{kg} \mathrm{SC}-560$, a selective COX-1 inhibitor, inhibited tumor growth by a statistically significant $36 \%$ over the same period of time [88]. Immunohistochemistry revealed significantly lower KI-67 expression in the tumors excised from all three (SC-560, celecoxib, and SC-560/celecoxib) treatment groups than the tumors from the control group [88]. TUNEL assays detected significant increases in fragmented DNA in the SC-560 or celecoxib treated groups, and a $167 \%$ increase, over the control group, in the SC-570/celecoxib group [88].

Another study confirmed that pharmacological inhibition of COX-2, but not COX-1, dramatically reduces cellular proliferation in vitro. Treatment of BxPC-3 cells, a COX-2 positive pancreatic adenocarcinoma cell line, with $25 \mu \mathrm{M}$ or $50 \mu \mathrm{M}$ NS-398, a selective COX-2 inhibitor, inhibited cell growth by $30 \%$ and $50 \%$ respectively [89]. Further, this study established a link between COX2 expression and angiogenesis, the formation of new blood vessels that is required for tumor growth beyond 2-3 mm [1]. Pretreatment of BxPC-3 cells with $50 \mu \mathrm{M}$ NS-398 inhibited BxPC-3 induced Bovine Aortic Endothelial Cell migration, a crucial step of the angiogenic process, by $68 \%$; while treatment with $5 \mu \mathrm{M} \mathrm{PGE}$ after $50 \mu \mathrm{M}$ NS-398 partially restored BAEC migration. Further, endothelial cells seeded onto Matrigels and cocultured with BxPC-3 cells differentiated and developed into tube like structures in vitro, a phenomenon that is not observed in control groups lacking cancer cells or experimental groups that are continuously exposed to $50 \mu \mathrm{M}$ NS-398. Mouse Matrigel plug assay, an in vivo angiogenesis model, further confirmed the angiogenesis inducing potential of COX-2 products. Mice injected with culture medium derived from BxPC-3 cells presented a 10 fold increase, over the control group, in neovascularization; versus only a 2.9 fold increase in mice injected with culture medium derived from AsPC-1, a COX-2 negative cell line. Furthermore, pretreatment of BxPC-3 cells with $50 \mu \mathrm{M}$ NS-398 completely abrogated the derived culture medium's ability to stimulate neovascularization in these mice [89].

There are numerous other studies in support of the anti-cancer activities of COX-2 inhibitors, most notably celecoxib. However, it should be noted that not all anticancer activities of celecoxib or other NSAIDs can be contributed to inhibition of COX activities and reduction of prostanoid biosynthesis. In fact, for example, the induction of apoptosis of celecoxib has been found not associated with inhibition of COX-2 [90]. As a small molecule, celecoxib can have off target activities, as evidenced by the observations that the acute cytotoxicity of celecoxib can be separated from its inhibition of COX-2. In addition to celecoxib, other NSAIDs can exert anti-proliferative or cytotoxic effects through various COX-independent 
mechanisms [91]. The studies raised interesting questions regarding various off target effects of NSAIDs including COX-2 selective inhibitors.

\section{Cyclooxygenase involvement in tumor invasion and metastasis}

Given the involvement of COX-2 in cancer development and progression, clinical surveys have, not surprisingly, found strong positive correlations between high COX-2 expression and unfavorable clinical outcomes, especially metastasis [79]. The risk of death for patients with COX-2 positive ovarian cancer is 2.8 times that of the patients with COX-2 negative ovarian cancer - COX-2 expression, in this case, is a more predictive prognosis indicator than FIGO stage or histological grade [79].

COX-2 has been shown to promote invasive phenotypes through increased expression of matrix metalloproteinases (MMP) 1 and 2 to break down the extracellular matrix and decrease cell-cell adhesion, in human colon cancer cells and the hyaluronate receptor CD44, glycoprotein receptors involved in cell adhesion and migration, in colon [80] and non small-cell lung [1] cancers. Other studies have also confirmed that there is significantly higher COX-2 and VEGF-C expressions in lymph node metastasis (LNM) positive than in LNM negative cervical and lung cancers specimens [86]. Experiments have shown that in vitro siRNA knock-down of VEGF-C in A548 lung cancer cells partially restored epithelial phenotype, significantly decreased specific mesenchymal markers, and drastically decreased the side population of cells expressing cancer stem cell markers [92], which are speculated to contribute to the invasiveness and chemo- and radioresistance in tumors [93]. Pharmacological inhibition of COX enzymes by NSAIDs has been shown to lower serum VEGF-C levels in patients. Celecoxib, when orally administered, lowers VEGF serum levels by as much as $15 \%-25 \%$ [94]. Orally administered $50 \mathrm{mg} / \mathrm{kg}$ rofecoxib, another selective COX-2 inhibitor, predictably decreased the incidence of liver metastasis in BALB/c mice carrying implanted MC-26 murine colon cancer cells in their splenic subcapsule. These treated mice also had a far lower mortality rate than the control group, $10 \%$ versus $90 \%$ after 30 days [95]. The studies generally support the rationale of using COX-2 inhibitor to reduce tumor invasion and metastasis. However, due to the adverse effects of long term use of COX-2 inhibitors, it is still unclear whether there is a therapeutic window of using COX-2 inhibitors in reducing tumor invasion and metastasis in a safe and effective way.

Among the downstream of COX, PGE synthase is extensively studied for its potential role in tumor progression and already subjected to a number of reviews [96-100]. Evidence accumulates suggesting another downstream enzyme, thromboxane (TX) synthase in tumor progression. TX synthase converts $\mathrm{PGG}_{2}$ to $\mathrm{TXA}_{2}$. Astrocytoma cells selected for migratory ability revealed that enhanced motility is coincided with up-regulated expression of a TX synthase homolog [80]. Increased expression of TX synthase was found in prostate cancer specimens with advanced stage and perineural invasion [101]. Further in vitro experiments have confirmed that up-regulation of TX synthase increases the migratory ability of DU-145 cells, a moderately invasive prostate cancer cell line, and SQ-29548, a potent and selective TXA2 receptor antagonist, interferes with the migratory ability of these cells [101]. NS-398 inhibited TXA 2 synthesis in vitro by roughly $80 \%$, and combination treatment with piroxicam, a selective COX-1 inhibitor, and NS-398 reduced $\mathrm{TXA}_{2}$ synthesis by 95\% [101]. Therefore, in cancer cells, both COX isoforms can contribute $\mathrm{PGH}_{2}$ to form $\mathrm{TXA}_{2}$. Further studies of enzymes downstream of COX may provide target of intervention to reduce tumor invasion and metastasis as results of aberrant COX-2 or COX-1 expression and activities.

\section{Prostanoid receptors and cancer}

There is even evidence of COX product dependence in malignant tissues that do not exhibit aberrant endogenous COX expressions. One study showed that COXdeficient pancreatic cancer cell lines AsPC1 and Mia$\mathrm{PaCa} 2$ undergo significant increases in cell proliferation after treatment with concentrations of $\mathrm{PGE}_{2}$ as low as $1 \mu \mathrm{M}$; and these cells showed markedly slowed growth after siRNA knockdown of MRP4, the main prostaglandin transporter [102]. This suggests that prostanoids are essential to cancer progression, and abnormally high concentrations of prostanoids, such as $\mathrm{PGE}_{2}$, in the cellular microenvironment, produced by non- or premalignant tissues that over-express COX enzymes, may affect cancer progression and clinical outcomes just as much as endogenous COX over-expression.

The receptors for prostanoids are involved in many pathophysiological processes, and they have been often linked to various diseases such as inflammation, atherosclerosis and cancer. For instance, it has been shown that prostaglandin $\mathrm{E}_{2}$ induced activation of EP4 mediates RCC7 cell invasion [103]. Specifically, EP4 that is expressed in renal cancer cells initiates a variety of signaling cascades that are transduced by activated $\mathrm{G \alpha}_{\mathrm{s}}$. This signal transduction pathway further encompasses production of the second messenger cAMP by adenylyl cyclase and subsequent activation of Rap signaling that promotes cell migration [103].

Another study examined the role of EP receptors in invasiveness of breast cancer cells of murine (C3L5) and human (MDA-MB-231 and MCF-7) origin [104]. The major finding of this study was that breast cancer cells with high metastatic potential (C3L5 and MDA-MB-231) 
produced higher amounts of prostaglandin $E_{2}$ than the noninvasive MCF7 cell line [104]. Moreover, the mRNA profiles for EP receptors were evaluated. It was observed that human cell lines expressed all four receptors but the murine cell line lacked expression of EP2 receptor. EP4 induced activation of the effector molecule PKA was implicated in an autocrine $\mathrm{PGE}_{2}$ migratory activity. Interestingly, the basal migration index of MCF7 (1.3+/-0.4\%) cells was lower than those of MDA-MB-231 (28.1+/-6.4\%), proving dissimilar migratory abilities [104].

These results are in close agreement with the implication of the EP1 signaling pathway in the local invasiveness and metastasis of oral squamous cell carcinoma [105]. This study provided evidence that $\mathrm{PGE}_{2}$ increases cell motility by activation of EP1, PKC $\delta$, c-Src, c-Jun, and AP-1 signal cascade [105]. The transcriptional activity of c-Jun leads to expression of ICAM-1 that mediates adhesion-dependent cell-to-cell interactions and is known to facilitate movement [105].

Interestingly, another study demonstrated that decreased expression of EP1 at RNA level correlated with a poor prognosis in breast cancer patients [106]. Microarray analysis data suggest that the majority of tumors from European American women (72\%) that showed significant levels of EP1 mRNA were correlated with a higher survival rate than African American women who expressed very low levels of EP1 mRNA [106]. Nuclear localization of EP1 had a beneficial impact on survival [106].

Evidence suggests that EP2 mediated signaling plays a pivotal role in the proliferation and apoptosis of human hepatoma cell lines (HepG2 and SMMC-7721) [107]. Results indicated that expression of EP2 directly correlated with elevated expression of the anti-apoptotic protein Bcl-2 [107]. In contrast, paeoniflorin induced apoptosis in liver cancer cells by suppressing expression of EP2 and augmenting Bax and cleaved caspase-3 levels [107].

Furthermore, the biological capability of prostaglandin $\mathrm{E}_{2}$ to induce EP4 activation and metastasis of breast cancer cells involves a mechanism that requires natural killer cells [108]. NK cells have been demonstrated to express all four EP receptors, but preferential activation of EP4 by $\mathrm{PGE}_{2}$ is responsible for inhibition of $\mathrm{NK}$ cell migration and cytokine secretion [108]. The compromised function of NK cells contributes to suppression of critical NK cell functions involved in control of metastasis [108].

Recent studies have demonstrated that $\mathrm{PGD}_{2}$ coupling to DP receptor promotes inhibitory effects on NK cell functions [109]. The considerable clinical implication in cancer derives from the fact that DP is expressed on human NK cells and $\mathrm{PGD}_{2}$ mediated activation of this receptor leads to inhibition of the cytotoxic and chemotactic effects as well as decreased accumulation of type 1 cytokine. Intriguingly, this inhibition prevents NK cell migration toward the inflammatory site [109]. A low dose $(10 \mathrm{nM})$ of $\mathrm{PGD}_{2}$ is sufficient to inhibit NK functions. This anti-inflammatory response may prove to be beneficial in cancer treatment [109]. The therapeutic potential of DP agonists has also been demonstrated by the fact that DP deficiency enhances tumor progression and angiogenesis [110]. Specifically, DP expression in endothelial cells decelerates vascular leakage which results in decreased tumor angiogenesis and tumor growth [110]. Further, it has been speculated that both aldo-keto reductase AKR1C2 and AKR1C3 mediated PGD 2 catabolism enhanced prostate cancer cell proliferation via FP and PI3K/Akt signaling pathways [111].

Studies have highlighted the mechanism of FP receptor signaling in alteration of epithelial cell invasion and endothelial cell function in endometrial cancer [112]. Ligand $\left(\mathrm{PGF}_{2 \mathrm{a}}\right)$ induced activation of $\mathrm{FP}$ in the epithelial cells of endometrial adenocarcinoma, results in stimulation of the calmodulin-NFAT signaling pathway [112]. This signaling cascade leads to elevated ADAMTS1 which functions in an autocrine/paracrine manner to promote epithelial cell invasion via ECM and a paracrine manner to inhibit endothelial cell proliferation [112]. The same group also suggested the presence of a positive feedback loop that regulates neoplastic epithelial cell function in endometrial adenocarcinoma [88]. Specifically, COX-2 induced production of $\mathrm{PGF}_{2 \mathrm{a}}$ stimulates its binding to the FP receptor and subsequent $G_{q}$ and 1,4,5triphosphate activation [88]. The later results in stimulation of ERK signaling and subsequent enhanced production of fibroblast growth factor 2 (FGF2) and expression of additional COX2. FGF2 association with FGFR1 promotes phosphorylation of ERK and enhanced cellular proliferation [88].

Further, it has been proposed that $\mathrm{PGF}_{2 \mathrm{a}}-\mathrm{FP}$ association potentiates angiogenesis in endometrial adenocarcinoma through activation of EGFR and subsequent ERK1/2 signaling. This resulted in enhanced signaling and transcription of the vascular endothelial growth factor (VEGF) [113].

Expression of the prostacyclin receptor IP is indicative of the angiogenic phenotype of tumor endothelial cells according to findings that suggested that migration and tube formation of TEC were inhibited by the IP receptor antagonist RO1138452 [102]. According to the same study, IP receptor is required for induction of angiogenesis. It has been speculated that stable prostacyclin analogues reduce lung and lymph node metastasis in mammary carcinoma models [114].

It has been reported that thromboxane $A_{2}$ receptors $\left(\mathrm{TXA}_{2} \mathrm{R}\right.$, or TP) play a pivotal role in cell transformation and proliferation of neoplastic human lung cells through expression of Nurr1 [115]. Nurr1 an orphan nuclear receptor has been identified as the downstream effector of 
TP signaling. Agonist (I-BOP) induced activation of TP and stimulation of Nurr1 expression was mediated via the PKA/CREB, PKC and ERK signaling pathways in H157 cells [115]. Nurr1 is believed to mediate cyclin D1 expression and cell proliferation. Moreover, constitutive interaction between TP $\alpha / \mathrm{TP} \beta$ and PRK1 leads to phosphorylation of histone $\mathrm{H} 3$ at $\mathrm{Thr}$ [11] and associated cell migration and proliferation in prostate carcinoma cell lines [116]. It has been noted that TP $\beta$ could be used as a predictor of prognosis for bladder cancer, since bladder cancer cell lines express this isoform unlike SV-HUC that exclusively express TP $\alpha$ [117]. TP $\beta$ expression positively correlates with cell proliferation, migration and invasion in bladder cancer [117]. In prostate cancer, activation of TP could lead to cytoskeletal reorganization and rapid cell contraction through activation of small GTPase RhoA [118]. Blockade of TP activation compromised tumor cell motility [118].

Despite the above described studies indicating the involvement of prostanoid receptors in cancer (Figure 1), it still remains to be defined when and how prostanoid receptors are enlisted during tumor formation and progression, and whether prostanoid receptors can be a target of intervention for cancer prevention and treatment.

\section{Targeting cyclooxygenases for cancer prevention and treatment using NSAIDs}

Experiments in the laboratory have indicated that COX inhibitors are promising candidates that could be used to treat cancer. So far, COX inhibitors have been shown not only to inhibit tumor initiation and accelerated progression, but also to preferentially affect cancer cells. At least one study has reported that in vitro $100 \mu \mathrm{M}$ NS398 treatments markedly reduced the viability of LNCaP, an androgen-sensitive human prostate adenocarcinoma cell line, but not the viability of human fetal prostate fibroblasts. Analysis of the genomic DNA extracted from these cells also showed that only malignant cells experienced increases in DNA fragmentation, 11 folds to be precise, after three days treatment [119].

These findings, however, have not been translated successfully into the clinics. Initial findings show that COX inhibitors are ineffective at preventing polyp growth in patients with familial adenomatous polyposis coli (FAP) at the anti-inflammatory doses, but long term use of these drugs at higher doses are associated with serious side effects. Nonselective COX inhibitors are often associated with gastrointestinal problems, including serious, albeit rare, gastric and duodenal perforations, and selective COX-2 inhibitors are associated with significantly increased risk of acute myocardial infarctions in already at-risk patients [1], although more recent studies show that celecoxib can be safely administered at $800 \mathrm{mg} /$ day in combination with other treatments [120].
So far, clinical trials involving treatment regiments that target the COX pathway have produced mixed results. While, low dose celecoxib used in combination with temozolomide, a DNA methylation/alkylation agent often used to treat glioblastoma multiforme and melanomas after gross surgical resection and radiotherapy, does prolong progression free survival for patients with glioblastoma multiforme, it also, rather counter-intuitively, increases the likelihood of distant metastases by 3 to 12 folds [121]. Orally administered $400 \mathrm{mg}$ celecoxib twice a day decreased the KI-67 index in bronchi tissues extracted from former smokers by an average of $34 \%$ over six month, compared to only $3.8 \%$ in the placebo group [122], while the same dose taken in combination with palliative chemotherapy for patients with non-small cell lung cancer (NSCLC) provided no survival benefit over the placebo [123]. Patients who take selective COX2 inhibitors for one year or more are at a lower risk for colorectal cancers, but at a significantly higher risk for breast and hematological cancers [124]. These mixed results make it necessary to further elucidate the mechanism of actions of NSAIDs in reducing cancer incidence and/or mortality so that a subset of patients can be identified for targeted use of NSAIDs for cancer prevention or treatment.

\section{Targeting the prostanoid signaling pathways for cancer treatment}

Long-term administration of patients with COX-2 selective inhibitors may have consequences such as severe cardiovascular complications. Due to this major drawback of the current therapeutic strategies aiming at inhibition of cyclooxygenase activity, efforts are currently underway to discover administration of prostanoid signaling pathway antagonists.

Prostacyclin $\left(\mathrm{PGI}_{2}\right)$ is the main product of arachidonate metabolism and has pleiotropic biological activities such as vasodilation. Its role as an endogenous inhibitor of platelet aggregation has been further investigated as a beneficial activity to reduce tumor metastatic process [125]. Specifically, a study indicated that lungs treated with $\mathrm{PGI}_{2}$ had 40-50 times fewer metastatic nodes when compared to the positive control [126]. The same study showed that treatment of mice with $\mathrm{PGI}_{2}$, resulted in a $10 \%$ decrease of metastatic cell adhesion to the endothelial tubules [126]. An alternative approach for the therapeutic targeting of prostanoid signaling, was the examination of the inhibitory effect of COX selective inhibitors on prostacyclin. A significant inhibition of prostacyclin synthase activity was observed in human endothelial cells, following treatment with rofecoxib [127]. Currently a plethora of prostacyclin receptor (IP receptor) agonists such as iloprost, cicaprost and carbacyclin have been reported. However, only a few highly selective IP receptor antagonists 
such as 2-[4-(1H-indol-4-yloxymethyl)-benzyloxycarbonylamino]-3-phenyl-propionic acid are known [128]. It still remains to be elucidated when and how $\mathrm{PGI}_{2}$ and its receptor can be exploited for cancer treatment.

Reports regarding the major COX-2 metabolite $\mathrm{PGE}_{2}$ and its association with the development of colorectal cancer and other malignancies through its cognate receptors have been extensively published. Experimental evidence supports that ONO-8711, an E-prostanoid receptor antagonist, inhibits $\mathrm{PGE}_{2}$ signaling without any interference on the $\mathrm{PGF}_{2 \mathrm{a}}$ production or PGIS expression [129]. The fact that it has no effect on prostacyclin production might render ONO-8711 as a safer chemopreventive agent regarding cardiovascular events [129]. Another study showed that indomethacin, a major NSAID, antagonizes human EP2 receptors. The unfavorable lack of efficacy and specificity of indomethacin led to the consideration of other therapeutic agents [130]. Epigallocatechin-3-gallate, a naturally occurring dietary compound extracted from green tea has been identified as a potent suppressor of cellular $\mathrm{PGE}_{2}$ biosynthesis [131]. The same substance has been shown to synergistically augment celecoxib-mediated suppression of $\mathrm{PGE}_{2}$ as well as decrease the amount of the COX-2 inhibitor (celecoxib) necessary for the production of the antitumoral effect [132].

Another eicosanod studied as a target for cancer prevention and treatment is the thromboxane $\mathrm{A}_{2}$ formed by the action of thromboxane $\mathrm{A}_{2}$ synthase $\left(\mathrm{TXA}_{2} \mathrm{~S}\right)$. An approach that has been investigated is the inhibition of $\mathrm{TXA}_{2} \mathrm{~S}$, which involves selective suppression of thromboxane formation. Dazoxiben is an example of this class of drugs and prevents the conversion of $\mathrm{PGH}_{2}$ to $\mathrm{TXA}_{2}$. This drug shifts the direction of metabolism towards the production of $\mathrm{PGI}_{2}$ and $\mathrm{PGD}_{2}$ [133]. Researchers tested the effects of administration of pirmagrel, a thromboxane synthetase inhibitor in 10 renal allograft recipients with cyclosporine nephrotoxicity and found that it effectively suppresses the production of $\mathrm{TXA}_{2}$ as indicated by the reduction in the levels of the inactive $\mathrm{TXB}_{2}$ (96\% mean suppression) and other thromboxane derived metabolites [134]. These results are in close agreement with decreased levels of $\mathrm{TXB}_{2}$ in serum during UK-37 $248 \mathrm{TXA}_{2} \mathrm{~S}$ inhibitor administration. In addition, the imidazole derivative UK 37248 increased the production of $\mathrm{PGE}_{2}$ and $\mathrm{PGF}_{2 \mathrm{a}}$ [135]. Another $\mathrm{TXA}_{2}$ synthase inhibitor OKY046 inhibits not only the production of $\mathrm{TXA}_{2}$ but also its release without increasing $\mathrm{PGI}_{2}$ synthesis [136]. Remarkably, E3040, a dual inhibitor of 5-lipoxygenase and thromboxane synthase at 30 and $100 \mathrm{mg} / \mathrm{kg}$ inhibited the synthesis of leukotriene B4 and thromboxane B2 but increased the production of $\mathrm{PGE}_{2}$ [137].

Further strategies have focused upon the direct blockade of the TP receptor. SQ29548 is a standard TP antagonist that has contributed to the investigation of TP mediated processes. Several data have indicated that domitroban (S-1452/S-145) which is a TP antagonist, is more potent than OKY046 ( $\mathrm{TXA}_{2} \mathrm{~S}$ inhibitor) and is capable of hampering cytokine synthesis [138]. Ramatoroban (Bay U3405) is a potent long lasting inhibitor of U46619 (TXA 2 agonist). Research has shown that it is effective after either intravenous or oral administration in male Dunkin Hartley guinea pigs with $\mathrm{ID}_{50}$ values of $600 \mathrm{ug} / \mathrm{kg}$ and $1.7 \mathrm{mg} / \mathrm{kg}$ respectively [139]. Extensive studies have shown that combined administration of aspirin with TP antagonist apigenin, essentially potentiates the inhibitory effect on the cyclooxygenase $\mathrm{TXA}_{2}$ pathway in the instance of aspirin failure to properly suppress the $\mathrm{TXA}_{2}$ pathway [140]. Other flavonoids such as genistein and luteolin have been shown to displace binding of radiolabeled SQ29548 by $>50 \%$ to different cell types [141]. Several lines of evidence suggest that a superior method for the reduction of $\mathrm{TXA}_{2}$ synthesis is the development of drugs that have dual functions as TP antagonists and thromboxane synthase inhibitors. The category of dual acting drugs includes: picotamide (G137), samixogrel (DTTX30) and BM-531 [142].

Most inhibitors of prostanoid signaling are developed for cardiovascular indications or as anti-inflammatory agents. Clearly more studies are needed to define the involvements of prostanoids in tumor formation and progression and to evaluate the utility of these proostanoid inhibitors in cancer prevention and treatment.

\section{Conclusion and perspective}

COX enzymes clearly become deregulated in cancers and all research indicate that these metabolic pathways are involved in carcinogenesis and tumor progression. Studies using animal models have demonstrated that these enzymes are promising targets for intervention; in vivo models consistently show that COX inhibitors inhibit tumor incidence, growth, and acquisition of invasive phenotypes. Unfortunately, these results have not yet been translated into the clinics successfully.

COX expression is indicative of poorer prognosis for cancer patients, but the biological effects of its metabolites are diverse and often in opposition. Most studies indicate that the ultimate fate and biological effect of $\mathrm{PGH}_{2}$ is largely tissue dependent, blind systemic inhibition of COX enzymes risks upsetting the delicate COX metabolite homeostasis, so it's not surprising that clinical trials have produced largely inconsistent results. Groups, however, have independently confirmed that selective inhibition or deletion of specific $\mathrm{PGE}_{2}, \mathrm{PGF}_{2 \alpha}$, $\mathrm{TXA}_{2}$ receptors produces many of the same effects as direct COX inhibition [143-146]. Further research into these specific downstream pathways should be 
conducted, since more targeted treatments are more likely to yield desirable results.

There is no complete account of how COX and LOX enzymes become deregulated in cancer. Even though the demand for this answer might be considered unreasonable, especially since many other unknowns that are far more likely to yield immediate therapeutic options still exist. This question, however, is scientifically intriguing and an answer is necessary for a holistic understanding of cancer biology. Studies have already reported that coadministration of COX and LOX inhibitors produces a synergistic effect. More recently, studies have reported that NSAID induced apoptosis coincides with increased 15 -LOX expression and activity $[147,148]$ and that celecoxib treatment may affect LTB4 levels in lung, colon and prostate cancers $[149,150]$ So far, evidence only hint that these pathways are connected or operate in concert. More research should be conducted to clarify this connection.

Finally, LOX isozymes oxygenate a diverse set of PUFAs, not just AA. Metabolites generated from other substrates often exert effects that oppose those of the AA metabolites. Studies have found correlations between dietary $\omega-6$ fatty acids and cancer [151], and at least one study has reported that dietary $\omega-3$ fatty acid supplements enhance anti-VEGF and COX inhibitor thearpies [152]. Research into this field can have profound impact on our understanding of nutrition and identify diets that supplement and enhance existing treatments.

\section{Competing interests}

The authors do not have any competing interests to declare.

\section{Authors' contributions}

VA drafted the portion of prostanoid receptors and cancer, CG drafted the portion of cyclooxygenases and cancer, DN revised the whole manuscript and approved the manuscript. All authors read and approved the final manuscript

\section{Acknowledgements}

Some works cited are supported by grants from the National Institutes of Health/National Cancer Institute (NIH/NCl) R01CA13345(D Nie) and Department of Defense Breast Cancer Research Program Idea Award W81XWH-08-1-0540 (D Nie).

Received: 20 September 2012 Accepted: 21 January 2013 Published: 6 February 2013

\section{References}

1. Fürstenberger $G$, Krieg $P$, Müller-Decker $K$, Habenicht AJR: What are cyclooxygenases and lipoxygenases doing in the driver's seat of carcinogenesis? Int J Cancer 2006, 119:2247-2254.

2. Chow LW, Loo WT, Toi M: Current directions for COX-2 inhibition in breast cancer. Biomed Pharmacother 2005, 59(Suppl 2):S281-S284.

3. Ryan PD, Goss PE: Adjuvant hormonal therapy in peri- and postmenopausal breast cancer. Oncologist 2006, 11:718-731.

4. Gierach $\mathrm{GL}$, et al: Nonsteroidal anti-inflammatory drugs and breast cancer risk in the National Institutes of Health-AARP Diet and Health Study. Breast Cancer Res 2008, 10:R38.

5. Chandrasekharan NV, et al: COX-3, a cyclooxygenase-1 variant inhibited by acetaminophen and other analgesic/antipyretic drugs: cloning, structure, and expression. Proc Natl Acad Sci 2002, 99:13926-13931.
6. Garavito RM, Mulichak AM: The structure of mammalian cyclooxygenases. Annu Rev Biophys Biomol Struct 2003, 32:183-206.

7. Kaduce $T L$, Figard PH, Leifur R, Spector AA: Formation of 9hydroxyoctadecadienoic acid from linoleic acid in endothelial cells. J Biol Chem 1989, 264:6823-6830

8. Chan BS, Satriano JA, Pucci M, Schuster VL: Mechanism of prostaglandin E2 transport across the plasma membrane of HeLa cells and Xenopus oocytes expressing the prostaglandin transporter "PGT". J Biol Chem 1998, 273:6689-6697.

9. Ushikubi $F$, et al: Impaired febrile response in mice lacking the prostaglandin E receptor subtype EP3. Nature 1998, 395:281-284.

10. Sugimoto $Y$, Segi E, Tsuboi K, Ichikawa A, Narumiya S: Female reproduction in mice lacking the prostaglandin $\mathrm{F}$ receptor. Roles of prostaglandin and oxytocin receptors in parturition. Adv Exp Med Biol 1998, 449:317-321.

11. Murata T, et al: Altered pain perception and inflammatory response in mice lacking prostacyclin receptor. Nature 1997, 388:678-682.

12. Lim H, et al: Cyclo-oxygenase-2-derived prostacyclin mediates embryo implantation in the mouse via PPARdelta. Genes Dev 1999, 13:1561-1574.

13. Coleman RA, Smith WL, Narumiya S: International Union of Pharmacology classification of prostanoid receptors: properties, distribution, and structure of the receptors and their subtypes. Pharmacol Rev 1994, 46:205-229.

14. Narumiya S, Sugimoto Y, Ushikubi F: Prostanoid receptors: structures, properties, and functions. Physio/ Rev 1999, 79:1193-1226.

15. Dubois RN, et al: Cyclooxygenase in biology and disease. FASEB J 1998 12:1063-1073.

16. Lydford SJ, McKechnie KC, Dougall IG: Pharmacological studies on prostanoid receptors in the rabbit isolated saphenous vein: a comparison with the rabbit isolated ear artery. Br J Pharmacol 1996, 117:13-20.

17. Funk CD, et al: Cloning and expression of a cDNA for the human prostaglandin E receptor EP1 subtype. J Biol Chem 1993, 268:26767-26772.

18. Sharif NA, Davis TL: Cloned human EP1 prostanoid receptor pharmacology characterized using radioligand binding techniques. J Pharm Pharmacol 2002, 54:539-547.

19. An S, Yang J, Xia M, Goetzl EJ: Cloning and expression of the EP2 subtype of human receptors for prostaglandin E2. Biochem Biophys Res Commun 1993, 197:263-270

20. Yang J, Xia M, Goetzl EJ, An S: Cloning and expression of the EP3-subtype of human receptors for prostaglandin E2. Biochem Biophys Res Commun 1994, 198:999-1006.

21. Bastien L, Sawyer N, Grygorczyk R, Metters KM, Adam M: Cloning, functional expression, and characterization of the human prostaglandin E2 receptor EP2 subtype. J Biol Chem 1994, 269:11873-11877.

22. Batshake B, Nilsson C, Sundelin J: Molecular characterization of the mouse prostanoid EP1 receptor gene. Eur J Biochem 1995, 231:809-814.

23. Regan JW, et al: Cloning of a novel human prostaglandin receptor with characteristics of the pharmacologically defined EP2 subtype. Mol Pharmacol 1994, 46:213-220.

24. Hizaki $\mathrm{H}$, et al: Abortive expansion of the cumulus and impaired fertility in mice lacking the prostaglandin E receptor subtype EP(2). Proc Natl Acad Sci USA 1999, 96:10501-10506.

25. Sheller JR, Mitchell D, Meyrick B, Oates J, Breyer R: EP(2) receptor mediates bronchodilation by PGE(2) in mice. J Appl Physiol 2000, 88:2214-2218.

26. Boie $Y$, et al: Molecular cloning and characterization of the four rat prostaglandin E2 prostanoid receptor subtypes. Eur J Pharmacol 1997, 340:227-241.

27. Katsuyama M, et al: The mouse prostaglandin E receptor EP2 subtype: cloning, expression, and northern blot analysis. FEBS Lett 1995, 372:151-156.

28. Kotani M, et al: Structural organization of the human prostaglandin EP3 receptor subtype gene (PTGER3). Genomics 1997, 40:425-434.

29. Namba $T$, et al: Alternative splicing of $C$-terminal tail of prostaglandin $E$ receptor subtype EP3 determines G-protein specificity. Nature 1993, 365:166-170.

30. Aoki J, et al: Signal transduction pathway regulating prostaglandin EP3 receptor-induced neurite retraction: requirement for two different tyrosine kinases. Biochem J 1999, 340(Pt 2):365-369.

31. Audoly LP, et al: Prostaglandin E-prostanoid-3 receptor activation of cyclic AMP response element-mediated gene transcription. J Pharmacol Exp Ther 1999, 289:140-148.

32. Hasegawa $H$, Negishi M, Ichikawa A: Two isoforms of the prostaglandin $E$ receptor EP3 subtype different in agonist-independent constitutive activity. J Biol Chem 1996, 271:1857-1860. 
33. Audoly LP, et al: Role of $\mathrm{EP}(2)$ and $\mathrm{EP}(3) \mathrm{PGE}(2)$ receptors in control of murine renal hemodynamics. Am J Physiol Heart Circ Physiol 2001, 280:H327-H333.

34. Fabre JE, et al: Activation of the murine EP3 receptor for PGE2 inhibits CAMP production and promotes platelet aggregation. J Clin Invest 2001, 107:603-610.

35. Sugimoto $Y$, Narumiya $S$, Ichikawa A: Distribution and function of prostanoid receptors: studies from knockout mice. Prog Lipid Res 2000, 39:289-314

36. Kiriyama $M$, et al: Ligand binding specificities of the eight types and subtypes of the mouse prostanoid receptors expressed in Chinese hamster ovary cells. Br J Pharmacol 1997, 122:217-224.

37. Kay AB, Barata L, Meng Q, Durham SR, Ying S: Eosinophils and eosinophilassociated cytokines in allergic inflammation. Int Arch Allergy Immunol 1997, 113:196-199.

38. Hayaishi O: Molecular mechanisms of sleep-wake regulation: a role of prostaglandin D2. Philos Trans R Soc Lond B Biol Sci 2000, 355:275-280.

39. Eguchi $N$, et al: Lack of tactile pain (allodynia) in lipocalin-type prostaglandin D synthase-deficient mice. Proc Natl Acad Sci USA 1999, 96:726-730.

40. Boie Y, Sawyer N, Slipetz DM, Metters KM, Abramovitz M: Molecular cloning and characterization of the human prostanoid DP receptor. J Biol Chem 1995, 270:18910-18916.

41. Nagata $\mathrm{K}$, et al: CRTH2, an orphan receptor of T-helper-2-cells, is expressed on basophils and eosinophils and responds to mast cell-derived factor(s). FEBS Lett 1999, 459:195-199.

42. Norel $X$, et al: Prostanoid receptors involved in the relaxation of human bronchial preparations. Br J Pharmacol 1999, 126:867-872

43. Walch $L$, et al: Prostanoid receptors involved in the relaxation of human pulmonary vessels. Br J Pharmacol 1999, 126:859-866.

44. Hirai $H$, et al: Prostaglandin D2 selectively induces chemotaxis in T helper type 2 cells, eosinophils, and basophils via seven-transmembrane receptor CRTH2. J Exp Med 2001, 193:255-261.

45. Monneret G, Gravel S, Diamond M, Rokach J, Powell WS: Prostaglandin D2 is a potent chemoattractant for human eosinophils that acts via a novel DP receptor. Blood 2001, 98:1942-1948.

46. Horton EW, Poyser NL: Uterine luteolytic hormone: a physiological role for prostaglandin F2alpha. Physiol Rev 1976, 56:595-651.

47. Barnard JW, Ward RA, Taylor AE: Evaluation of prostaglandin F2 alpha and prostacyclin interactions in the isolated perfused rat lung. J Appl Physiol 1992, 72:2469-2474.

48. Adams JW, et al: Prostaglandin F2 alpha stimulates hypertrophic growth of cultured neonatal rat ventricular myocytes. J Biol Chem 1996, 271:1179-1186.

49. Abramovitz $M$, et al: Cloning and expression of a cDNA for the human prostanoid FP receptor. J Biol Chem 1994, 269:2632-2636.

50. Pierce KL, Fujino H, Srinivasan D, Regan JW: Activation of FP prostanoid receptor isoforms leads to Rho-mediated changes in cell morphology and in the cell cytoskeleton. J Biol Chem 1999, 274:35944-35949.

51. Muller K, Krieg P, Marks F, Furstenberger G: Expression of PGF(2alpha) receptor mRNA in normal, hyperplastic and neoplastic skin. Carcinogenesis 2000, 21:1063-1066.

52. Nakajima T, et al: New Fluoroprostaglandin F(2alpha) Derivatives with Prostanoid FP-Receptor Agonistic Activity as Potent Ocular-Hypotensive Agents. Biol Pharm Bull 2003, 26:1691-1695.

53. Bunting S, Gryglewski R, Moncada S, Vane JR: Arterial walls generate from prostaglandin endoperoxides a substance (prostaglandin $\mathrm{X}$ ) which relaxes strips of mesenteric and coeliac ateries and inhibits platelet aggregation. Prostaglandins 1976, 12:897-913.

54. Moncada S: Eighth Gaddum Memorial Lecture. University of London Institute of Education, December 1980. Biological importance of prostacyclin. Br J Pharmacol 1982, 76:3-31.

55. Moncada S, Higgs EA, Vane JR: Human arterial and venous tissues generate prostacyclin (prostaglandin $\mathrm{x}$ ), a potent inhibitor of platelet aggregation. Lancet 1977, 1:18-20.

56. Vane JR, Botting RM: Pharmacodynamic profile of prostacyclin. Am J Cardiol 1995, 75:3A-10A

57. Smith WL, DeWitt DL, Garavito RM: Cyclooxygenases: structural, cellular, and molecular biology. Annu Rev Biochem 2000, 69:145-182.

58. McAdam BF, et al: Systemic biosynthesis of prostacyclin by cyclooxygenase (COX)-2: the human pharmacology of a selective inhibitor of COX-2. Proc Natl Acad Sci USA 1999, 96:272-277.

59. Catella-Lawson F, et al: Effects of specific inhibition of cyclooxygenase-2 on sodium balance, hemodynamics, and vasoactive eicosanoids. J Pharmacol Exp Ther 1999, 289:735-741.
60. Brock TG, McNish RW, Peters-Golden M: Arachidonic acid is preferentially metabolized by cyclooxygenase-2 to prostacyclin and prostaglandin E2 J Biol Chem 1999, 274:11660-11666

61. Armstrong RA, Lawrence RA, Jones RL, Wilson NH, Collier A: Functional and ligand binding studies suggest heterogeneity of platelet prostacyclin receptors. Br J Pharmacol 1989, 97:657-668.

62. Namba T, et al: cDNA cloning of a mouse prostacyclin receptor. Multiple signaling pathways and expression in thymic medulla. J Biol Chem 1994 269:9986-9992.

63. Breyer RM, Bagdassarian CK, Myers SA, Breyer MD: Prostanoid receptors: subtypes and signaling. Annu Rev Pharmacol Toxicol 2001, 41:661-690.

64. Smyth EM, Austin SC, Reilly MP, FitzGerald GA: Internalization and sequestration of the human prostacyclin receptor. J Biol Chem 2000, 275:32037-32045

65. Dorn GW 2nd, Sens D, Chaikhouni A, Mais D, Halushka PV: Cultured human vascular smooth muscle cells with functional thromboxane $A 2$ receptors: measurement of U46619-induced 45calcium efflux. Circ Res 1987, 60:952-956.

66. Pakala R, Willerson JT, Benedict CR: Effect of serotonin, thromboxane A2, and specific receptor antagonists on vascular smooth muscle cell proliferation. Circulation 1997, 96:2280-2286

67. FitzGerald GA: Mechanisms of platelet activation: thromboxane A2 as an amplifying signal for other agonists. Am J Cardio/ 1991, 68:11B-15B.

68. Ali S, Davis MG, Becker MW, Dorn GW 2nd: Thromboxane A2 stimulates vascular smooth muscle hypertrophy by up-regulating the synthesis and release of endogenous basic fibroblast growth factor. J Biol Chem 1993, 268:17397-17403.

69. Hirata $M$, et al: Cloning and expression of CDNA for a human thromboxane A2 receptor. Nature 1991, 349:617-620.

70. Raychowdhury MK, et al: Alternative splicing produces a divergent cytoplasmic tail in the human endothelial thromboxane $\mathrm{A} 2$ receptor. J Biol Chem 1995, 270:7011.

71. Miggin SM, Kinsella BT: Expression and tissue distribution of the mRNAs encoding the human thromboxane $A 2$ receptor (TP) alpha and beta isoforms. Biochim Biophys Acta 1998, 1425:543-559.

72. Needleman P, Wyche A, Raz A: Platelet and blood vessel arachidonate metabolism and interactions. J Clin Invest 1979, 63:345-349.

73. Cogolludo A, Moreno L, Bosca L, Tamargo J, Perez-Vizcaino F: Thromboxane A2-induced inhibition of voltage-gated $\mathrm{K}+$ channels and pulmonary vasoconstriction: role of protein kinase Czeta. Circ Res 2003, 93:656-663

74. Sullivan P, Smyth EM: Herterodimerization of the $a$ and $b$ isoforms of the human thromboxane receptor. Arterioscler Thromb Vasc Biol 2002, 22:878.

75. Powles TJ, Dowsett M, Easty GC, Easty DM, Neville AM: Breast-cancer osteolysis, bone metastases, and anti-osteolytic effect of aspirin. Lancet 1976, 307:608-610.

76. Sung S, et al: Overexpression of cyclooxygenase-2 in NCl-H292 human alveolar epithelial carcinoma cells: Roles of p38 MAPK, ERK-1/2, and PI3K/PKB signaling proteins. J Cell Biochem 2011, 112:3015-3024.

77. Kim BH, et al: Cyclooxygenase-2 overexpression in chronic inflammation associated with benign prostatic hyperplasia: is it related to apoptosis and angiogenesis of prostate cancer? Korean J Urol 2011, 52:253-259.

78. Kulkarni S, et al: Cyclooxygenase-2 Is Overexpressed in Human Cervical Cancer. Clin Cancer Res 2001, 7:429-434.

79. Wang M, He Y, Shi L, Shi C: Multivariate analysis by Cox proportional hazard model on prognosis of patient with epithelial ovarian cancer. Eur J Gynaecol Oncol 2011, XXXII:7.

80. Nie D: Cyclooxygenases and lipoxygenases in prostate and breast cancers. Front Biosci 2007, 12:1574-1585.

81. Park S-W, et al: he influence of cyclooxygenase- 1 expression on the efficacy of cyclooxygenase-2 inhibition in head and neck squamous cell carcinoma cell lines. Anti-Cancer Drugs, 22:416-423. doi:10.1097/ CAD.0b013e32834279f1.

82. Langenbach R, Loftin CD, Lee C, Tiano H: Cyclooxygenase-deficient Mice: A Summary of Their Characteristics and Susceptibilities to Inflammation and Carcinogenesis. Ann N Y Acad Sci 1999, 889:52-61.

83. Tiano HF, et al: Deficiency of Either Cyclooxygenase (COX)-1 or COX-2 Alters Epidermal Differentiation and Reduces Mouse Skin Tumorigenesis. Cancer Res 2002, 62:3395-3401.

84. Rundhaug JE, Mikulec C, Pavone A, Fischer SM: A role for cyclooxygenase2 in ultraviolet light-induced skin carcinogenesis. Mol Carcinog 2007, 46:692-698. 
85. Müller-Decker $K$, et al: Transgenic cyclooxygenase-2 overexpression sensitizes mouse skin for carcinogenesis. Proc Natl Acad Sci 2002, 99:12483-12488.

86. Liu H, et al: COX-2 expression is correlated with VEGF-C lymphangiogenesis and lymph node metastasis in human cervical cancer. Microvasc Res 2011, 82:131-140.

87. Williams CS, Tsujii M, Reese J, Dey SK, DuBois RN: Host cyclooxygenase-2 modulates carcinoma growth. J Clin Invest 2000, 105:1589-1594.

88. Sales KJ, Boddy SC, Williams AR, Anderson RA, Jabbour HN: F-prostanoid receptor regulation of fibroblast growth factor 2 signaling in endometrial adenocarcinoma cells. Endocrinology 2007, 148:3635-3644.

89. Chu J, Lloyd FL, Trifan OC, Knapp B, Rizzo MT: Potential Involvement of the Cyclooxygenase-2 Pathway in the Regulation of Tumor-associated Angiogenesis and Growth in Pancreatic Cancer1. Mol Cancer Ther 2003, 2:1-7.

90. Chuang $\mathrm{HC}$, Kardosh A, Gaffney KJ, Petasis NA, Schonthal AH: COX-2 inhibition is neither necessary nor sufficient for celecoxib to suppress tumor cell proliferation and focus formation in vitro. Mol Cancer 2008, 7:38.

91. Tegeder I, Pfeilschifter J, Geisslinger G: Cyclooxygenase-independent actions of cyclooxygenase inhibitors. FASEB J 2001, 15:2057-2072.

92. Khromova N, Kopnin P, Rybko V, Kopnin BP: Downregulation of VEGF-C expression in lung and colon cancer cells decelerates tumor growth and inhibits metastasis via multiple mechanisms. Oncogene 2012, 31:1389-1397.

93. Schwarz-Cruz-y-Celis A, M-ZJ: Cancer stem cells. Rev 2011, 63:179-186.

94. Halamka M, et al: Plasma levels of vascular endothelial growth factor during and after radiotherapy in combination with celecoxib in patients with advanced head and neck cancer. Oral Oncol 2011, 47:763-767.

95. Yao M, et al: Inhibition of Cyclooxygenase-2 by Rofecoxib Attenuates the Growth and Metastatic Potential of Colorectal Carcinoma in Mice. Cancer Res 2003, 63:586-592.

96. Wang MT, Honn KV, Nie D: Cyclooxygenases, prostanoids, and tumor progression. Cancer Metastasis Rev 2007, 26:525-534.

97. Muller-Decker K, Furstenberger G: The cyclooxygenase-2-mediated prostaglandin signaling is causally related to epithelial carcinogenesis. Mol Carcinog 2007, 46:705-710.

98. Nakanishi M, Gokhale V, Meuillet EJ, Rosenberg DW: mPGES-1 as a target for cancer suppression: A comprehensive invited review "Phospholipase A2 and lipid mediators". Biochimie 2010, 92:660-664.

99. Menter DG, Schilsky RL, DuBois RN: Cyclooxygenase-2 and cancer treatment: understanding the risk should be worth the reward. Clin Cancer Res 2010, 16:1384-1390.

100. Radmark O, Samuelsson B: Microsomal prostaglandin E synthase-1 and 5-lipoxygenase: potential drug targets in cancer. $J$ Intern Med 2010, 268:5-14

101. Nie D, et al: Differential expression of thromboxane synthase in prostate carcinoma: role in tumor cell motility. Am J Pathol 2004, 164:429-439.

102. Osawa T, et al: Prostacyclin receptor in tumor endothelial cells promotes angiogenesis in an autocrine manner. Cancer Sci 2012, 103:1038-1044.

103. Wu J, et al: Prostaglandin E2 regulates renal cell carcinoma invasion through the EP4 receptor-Rap GTPase signal transduction pathway. J Biol Chem 2011, 286:33954-33962

104. Timoshenko AV, Xu G, Chakrabarti S, Lala PK, Chakraborty C: Role of prostaglandin E2 receptors in migration of murine and human breast cancer cells. Exp Cell Res 2003, 289:265-274.

105. Yang SF, et al: Prostaglandin E2/EP1 signaling pathway enhances intercellular adhesion molecule 1 (ICAM-1) expression and cell motility in oral cancer cells. J Biol Chem 2010, 285:29808-29816.

106. Ma X, et al: Prostaglandin E receptor EP1 suppresses breast cancer metastasis and is linked to survival differences and cancer disparities. Mol Cancer Res 2010, 8:1310-1318.

107. Hu S, et al: Involvement of the prostaglandin E receptor EP2 in paeoniflorin-induced human hepatoma cell apoptosis. Anticancer Drugs 2013, 24:140-149.

108. Holt D, Ma X, Kundu N, Fulton A: Prostaglandin E(2) (PGE (2)) suppresses natural killer cell function primarily through the PGE(2) receptor EP4. Cancer Immunol Immunother 2011, 60:1577-1586.

109. Chen Y, Perussia B, Campbell KS: Prostaglandin D2 suppresses human NK cell function via signaling through D prostanoid receptor. J Immunol 2007, 179:2766-2773.

110. Murata T, et al: Role of prostaglandin D2 receptor DP as a suppressor of tumor hyperpermeability and angiogenesis in vivo. Proc Natl Acad Sci USA 2008, 105:20009-20014.
111. Wang S, Yang Q, Fung KM, Lin HK: AKR1C2 and AKR1C3 mediated prostaglandin D2 metabolism augments the PI3K/Akt proliferative signaling pathway in human prostate cancer cells. Mol Cell Endocrinol 2008, 289:60-66.

112. Keightley MC, Sales KJ, Jabbour HN: PGF2alpha-F-prostanoid receptor signalling via ADAMTS1 modulates epithelial cell invasion and endothelial cell function in endometrial cancer. BMC Cancer 2010, 10:488.

113. Sales KJ, et al: A novel angiogenic role for prostaglandin F2alpha-FP receptor interaction in human endometrial adenocarcinomas. Cancer Res 2005, 65:7707-7716.

114. Schirner M, Kraus C, Lichtner RB, Schneider MR, Hildebrand M: Tumor metastasis inhibition with the prostacyclin analogue cicaprost depends on discontinuous plasma peak levels. Prostaglandins Leukot Essent Fatty Acids 1998, 58:311-317

115. Li $\mathrm{X}$, Tai HH: Activation of thromboxane $A(2)$ receptors induces orphan nuclear receptor Nurr1 expression and stimulates cell proliferation in human lung cancer cells. Carcinogenesis 2009, 30:1606-1613.

116. Turner EC, et al: Identification of an interaction between the TPalpha and TPbeta isoforms of the human thromboxane $\mathrm{A} 2$ receptor with protein kinase C-related kinase (PRK) 1: implications for prostate cancer. J Biol Chem 2011, 286:15440-15457.

117. Moussa O, et al: Novel role of thromboxane receptors beta isoform in bladder cancer pathogenesis. Cancer Res 2008, 68:4097-4104

118. Nie D, et al: Thromboxane A2 receptors in prostate carcinoma: expression and its role in regulating cell motility via small GTPase Rho. Cancer Res 2008, 68:115-121.

119. Liu X-H, Yao S, Kirschenbaum A, Levine AC: NS398, a Selective Cyclooxygenase-2 Inhibitor, Induces Apoptosis and Down-Regulates bcl2 Expression in LNCaP Cells. Cancer Res 1998, 58:4245-4249.

120. Xue W-P, et al: Phase I clinical trial of nasopharyngeal radiotherapy and concurrent celecoxib for patients with locoregionally advanced nasopharyngeal carcinoma. Oral Oncol 2011, 47:753-757.

121. Seiz M, et al: Far-distant metastases along the CSF pathway of glioblastoma multiforme during continuous low-dose chemotherapy with temozolomide and celecoxib. Neurosurg Rev 2010, 33:375-381.

122. Mao JT, et al: Lung cancer chemoprevention with celecoxib in former smokers. Cancer Prevention Res 2011, 4:984-993.

123. Koch $A$, et al: Effect of celecoxib on survival in patients with advanced nonsmall cell lung cancer: A double blind randomised clinical phase III trial (CYCLUS study) by the Swedish Lung Cancer Study Group. Eur J Cancer 2011, 47:1546-1555.

124. Vinogradova Y, Coupland C, Hippisley-Cox J: Exposure to cyclooxygenase-2 inhibitors and risk of cancer: nested case-control studies. $\mathrm{Br} J$ Cancer 2011, 105:452-459.

125. Wang J, et al: Prostacyclin administration as a beneficial supplement to the conventional cancer chemotherapy. Med Hypotheses 2011, 76:695-696.

126. Cuneo KC, Fu A, Osusky KL, Geng L: Effects of vascular endothelial growth factor receptor inhibitor SU5416 and prostacyclin on murine lung metastasis. Anticancer Drugs 2007, 18:349-355.

127. Griffoni $C$, et al: Selective inhibition of prostacyclin synthase activity by rofecoxib. J Cell Mol Med 2007, 11:327-338.

128. Nakae $K$, et al: A prostacyclin receptor antagonist inhibits the sensitized release of substance $P$ from rat sensory neurons. J Pharmacol Exp Ther 2005, 315:1136-1142.

129. Kaneshiro $T$, et al: Inhibition of prostaglandin $E(2)$ signaling through the $\mathrm{EP}(1)$ receptor does not affect prostacyclin production in human endothelial cells. Prostaglandins Other Lipid Mediat 2009, 90:31-36.

130. Ikawa Y, Fujino H, Otake S, Murayama T: Indomethacin antagonizes EP(2) prostanoid receptor activation in LS174T human colon cancer cells. Eur J Pharmacol 2012, 680:16-21.

131. Koeberle A, et al: Green tea epigallocatechin-3-gallate inhibits microsomal prostaglandin E(2) synthase-1. Biochem Biophys Res Commun 2009, 388:350-354

132. Hardtner C, Multhoff G, Falk W, Radons J: (-)-Epigallocatechin-3-gallate, a green tea-derived catechin, synergizes with celecoxib to inhibit IL-1induced tumorigenic mediators by human pancreatic adenocarcinoma cells Colo357. Eur J Pharmacol 2012, 684:36-43.

133. Watts IS, Wharton KA, White BP, Lumley $P$ : Thromboxane $(T x) A 2$ receptor blockade and TxA2 synthase inhibition alone and in combination: comparison of anti-aggregatory efficacy in human platelets. Br J Pharmacol 1991, 102:497-505. 
134. Chouinard ML, et al: Pharmacokinetics and biochemical efficacy of pirmagrel, a thromboxane synthase inhibitor, in renal allograft recipients. Clin Pharmacol Ther 1992, 52:597-604.

135. Vermylen J, et al: Thromboxane synthetase inhibition as antithrombotic strategy. Lancet 1981, 1:1073-1075.

136. Suehiro T, et al: Thromboxane $A 2$ in preservation-reperfusion injury: the effect of thromboxane A2 synthetase inhibitor. J Surg Res 1996, 62:216-223.

137. Oketani K, Inoue T, Murakami M: Effect of E3040, an inhibitor of 5-lipoxygenase and thromboxane synthase, on rat bowel damage induced by lipopolysaccharide. Eur J Pharmacol 2001, 427:159-166.

138. Shi $\mathrm{H}$, et al: Effect of thromboxane $\mathrm{A} 2$ inhibitors on allergic pulmonary inflammation in mice. Eur Respir J 1998, 11:624-629.

139. Francis HP, Greenham SJ, Patel UP, Thompson AM, Gardiner PJ: BAY u3405 an antagonist of thromboxane A2- and prostaglandin D2-induced bronchoconstriction in the guinea-pig. Br J Pharmacol 1991, 104:596-602

140. Navarro-Nunez $L$, et al: Apigenin inhibits platelet adhesion and thrombus formation and synergizes with aspirin in the suppression of the arachidonic acid pathway. J Agric Food Chem 2008, 56:2970-2976.

141. Guerrero JA, et al: Flavonoids inhibit the platelet $\operatorname{TxA}(2)$ signalling pathway and antagonize $\operatorname{TxA}(2)$ receptors (TP) in platelets and smooth muscle cells. Br J Clin Pharmacol 2007, 64:133-144.

142. Nakahata N: Thromboxane A2: physiology/pathophysiology, cellular signal transduction and pharmacology. Pharmacol Ther 2008, 118:18-35.

143. Sung YM, He G, Fischer SM: Lack of Expression of the EP2 but not EP3 Receptor for Prostaglandin E2 Results in Suppression of Skin Tumor Development. Cancer Res 2005, 65:9304-9311.

144. Shoji Y, et al: Prostaglandin E receptor EP3 deficiency modifies tumor outcome in mouse two-stage skin carcinogenesis. Carcinogenesis 2005, 26:2116-2122.

145. Majima $M$, Amano $H$, Hayashi I: Prostanoid receptor signaling relevant to tumor growth and angiogenesis. Trends Pharmacol Sci 2003, 24:524-529.

146. Sales KJ, Milne SA, Williams ARW, Anderson RA, Jabbour HN: Expression, localization, and signaling of prostaglandin $\mathrm{F} 2 \hat{\mathrm{I}} \pm$ receptor in human endometrial adenocarcinoma: regulation of proliferation by activation of the epidermal growth factor receptor and mitogen-activated protein kinase signaling pathways. J Clin Endocrinol Metabol 2004, 89:986-993.

147. Clària J, Serhan CN: Aspirin triggers previously undescribed bioactive eicosanoids by human endothelial cell-leukocyte interactions. Proc Natl Acad Sci 1995, 92:9475-9479.

148. Xu XC, SS, Liang Z, Song S, Menter D, Subbarayan V, lyengar S, Tang DG, Lippman SM: Reduced 15S-lipoxygenase-2 expression in esophageal cancer specimens and cells and upregulation in vitro by the cyclooxygenase-2 inhibitor, NS398. Neoplasia 2003, 5:121-127.

149. Mao JT, et al: Modulation of pulmonary leukotriene B4 production by cyclooxygenase-2 inhibitors and lipopolysaccharide. Clin Cancer Res 2004, 10:6872-6878

150. Gao Y, Yokota R, Tang S, Ashton AW, Ware JA: Reversal of angiogenesis in vitro, induction of apoptosis, and inhibition of AKT phosphorylation in endothelial cells by thromboxane A(2). Circ Res 2000, 87:739-745.

151. Williams $C D$, et al: $A$ high ratio of dietary $n-6 / n-3$ polyunsaturated fatty acids is associated with increased risk of prostate cancer. Nutr Res 2011, 31:1-8

152. Sapieha P, et al: 5-Lipoxygenase Metabolite 4-HDHA Is a Mediator of the Antiangiogenic Effect of $\omega-3$ Polyunsaturated Fatty Acids. Sci Trans/ Med 2011, 3:69ra12

doi:10.1186/2045-3701-3-8

Cite this article as: Allaj et al:: Non-steroid anti-inflammatory drugs, prostaglandins, and cancer. Cell \& Bioscience 2013 3:8.

\section{Submit your next manuscript to BioMed Central and take full advantage of:}

- Convenient online submission

- Thorough peer review

- No space constraints or color figure charges

- Immediate publication on acceptance

- Inclusion in PubMed, CAS, Scopus and Google Scholar

- Research which is freely available for redistribution 